\title{
Wstęp
}

\section{Poszerzanie pola Zagłady}

Przemysław Czapliński

TEKSTY DRUGIE 2017, NR 2, S. 7-16

DOI: $10.18318 /$ td.2017.2.1

$\dot{\mathbf{S}}$ rodowiskowa historia Zagłady - zacznijmy od uproszczenia - zajmuje się relacjami między masową śmiercią i otoczeniem, w jakim śmierć się rozegrała. Powstała w punkcie przecięcia badań nad Holokaustem, ekologii i posthumanistyki. Nie jest prostą ich sumą, lecz wynikiem inspiracji, pożyczek i poszerzania pól badawczych.

Praktyka ta - jeśli wziąć pod uwagę historię badań nad Zagładą - długo osiągała dzisiejszy stan trwałego zakorzenienia i ciekawego rozgałęzienia'. Wydaje się, że naukowe i światopoglądowe warunki dla środowiskowych badań powstały dopiero w ciągu ostatnich trzech dekad, czyli mniej więcej od lat 9o. XX

1 Zob. np. E.P. Russell War and nature: fighting humans and insects with chemicals from world war 1 to Silent Spring, Cambridge University Press, New York 2001; A. Charlesworth, M. Addis Memorialization and the ecological landscapes of Holocaust sites: the cases of Plaszow and Auschwitz-Birkenau , "Landscape Research" 2002 No. 27, s. 229-251; A. Charlesworth The topography of genocide, w: The Historiography of the Holocaust, ed. by D. Stone, Royal Holloway, University of London 2004. W polskim piśmiennictwie - np. J. Małczyński Polityka natury w Auschwitz-Birkenau, "Teksty Drugie" 2014 nr 5; A. Ubertowska "Kamienie niepokoją się i stajq się agresywne". Holokaust w świetle ekokrytyki, „Poznańskie Studia Polonistyczne. Seria Literacka” 2015 nr 25. 
wieku². Wcześniej w badaniach nad Zagładą dominował paradygmat wyjątkowości skupiony na relacjach międzyludzkich.

Można ów wcześniejszy paradygmat nazwać patalogizującym, jako że prowadzone w jego ramach poszukiwania historyczne, politologiczne, socjologiczne czy nawet literackie wspierały myślenie o Holokauście nie tylko jako wydarzeniu wyjątkowym w dziejach Europy, lecz także jako zboczeniu z europejskiej drogi rozumu. Ucieczka od wolności (1941) Ericha Fromma, Hitler. Studium tyranii (1952) Alana Bullocka, Śmierć jest moim rzemiosłem (1953) Roberta Merle, Państwo stanu wyjq̨tkowego. Rzecz o systemie państwa i prawa Trzeciej Rzeszy (1964) Franciszka Ryszki, Refleksje oświęcimskie (1968) Antoniego Kępińskiego to modelowe, a przy tym ważne i wpływowe dzieła, które w równym stopniu wyjaśniały wojnę i Zagładę, co stwarzały ramy rozumienia tamtego etapu jako aberracji właśnie. Wynikało z nich, że Zagładę przygotowała seria cywilizacyjnych potknięć: patologizujące (junkierskie) wychowanie w rodzinie, resentyment spowodowany klęską wojenną i przegraną rewolucją, bezrobocie i kryzys gospodarczy, wykorzystanie demokracji dla pogwałcenia demokracji, nacjonalistyczna i rasistowska edukacja w szkole, wzbudzanie histerii i kierowanie gniewu ku Żydom przez kulturę masową, kryminogenne zasady selekcji do "grup specjalnych"i do obsady obozów... Wyprodukowana przez wyjątki i wymyślona jako narzędzie wyjątkowego działania Zagłada okazywała się zejściem z głównego szlaku kultury europejskiej wyznaczanego przez humanizm i postęp; jako pogwałcenie nowoczesnych ideałów wolności, równości i solidarności, jako zniszczenie uczłowieczającego charakteru pracy, a także odejście od chrześcijaństwa, stawała się wypadkiem z historiozofii, wcieleniem obcości, zaprzeczeniem europejskiego oświecenia.

Nowy paradygmat wyłonił się w latach 90. Ufundowały go dzieła nicujące dotychczasowe myślenie: Zygmunta Baumana Nowoczesność i Zagłada (1989; wyd. pol. 1992), Christophera Browninga Zwykli ludzie. 101 Policyjny Batalion Rezerwy i „ostateczne rozwiqzanie" w Polsce (1992; wyd. pol. 2000), Freda E. Katza Ordinary People and Extraordinary Evil: A Report on the Beguilings of Evil (1993) czy Daniela Goldhagena Gorliwi kaci Hitlera. Zwyczajni Niemcy i Holocaust (1996; wyd. pol. 1999). Oczywiście istniały antecedencje. Można je było znaleźć w Dialektyce oświecenia Theodora Adorna i Maxa Horkheimera, w książce Eichmann w Jerozolimie. Rzecz o banalności zła Hannah Arendt, a także w słynnych eksperymentach Stanleya Millgrama (1961, 1962) 3 i Philipa Zimbardo (1971).

2 Wtedy ukazują się pierwsze studia ujmujące Zagładę w kontekście środowiskowym - zob. W. Cronon A place for stories: nature, history and narrative, "Journal of American History" 1992 No. 87, s. 1375; J.E. Young Towards a Received History of the Holocaust, "History and Theory" 1997 No. 36, s. 21-43.

3 Zob. autorskie wyjaśnienia dotyczące posłuszeństwa i autorytetu: S. Milgram Behavioral study of obedience, "Journal of Abnormal and Social Psychology" 1963 No. 67, s. 371-378; tegoż Obedience to Authority: An Experimental View, Harper \& Row, New York 1974. 
Nowatorstwo wczesnych prac mogło jednak zostać wchłonięte i wykorzystane dopiero wtedy, gdy wycofano się z założeń o koniecznym przeciwieństwie Zagłady i oświecenia.

W paradygmacie wcześniejszym pytano o to, jakie wartości musiały zostać pogwałcone, aby Zagłada mogła się wydarzyć; w paradygmacie drugim, nazwijmy go „normalnościowym", badacze odwracają perspektywę i pytają, jakie ideały i zasady musiały zostać spełnione, jakie hierarchie społeczne - zbudowane, jakie instytucje utrwalone. W rezultacie odkryto, że warunkiem możliwości Zagłady było powiązanie jej procedur z najszerzej i najgłębiej pojętą normalnością. Normalnością zmilitaryzowaną i zdyscyplinowaną, obarczoną misją czystości i wielkości, ale mimo wszystko normalnością. Prowadzić badania w ramach nowego paradygmatu znaczyło pytać Zagładę o to, czego trzeba, aby zło stało się banalne - aby zabijanie na skalę masową mogło zostać włączone do normalnej tkanki życia społecznego. Zaczęto więc analizować ",codzienność” („zwykłych ludzi”, „zwyczajnych Niemców”, ,, normalne społeczeństwo"), dzięki czemu ujawniono głębokie struktury życia zbiorowego: europejski antysemityzm tkwiący w fundamentach chrześcijaństwa, znaczenie autorytetu i więzi grupowej dla współsprawstwa w zbrodni, doniosłość schematów działań i parcjalizacji zadań dla relatywizacji odpowiedzialności ${ }^{4}$. W świetle nowego paradygmatu Holokaust nie był patologiczną naroślą europejskiej kultury, lecz konsekwencją oświeconego kapitalizmu. A skoro tak, to warunki możliwości przeprowadzenia Zagłady istnieją nadal.

Koncepcję tę - za Adornem i Horkhaimerem - podjął Zygmunt Bauman w fundamentalnej książce Nowoczesność i Zagłada (1992). Bodaj najokrutniejsze, ale też i najbardziej odkrywcze zdanie autora, mówiło, że Holokaust to probierz państwa nowoczesnego. Inaczej rzecz ujmując: dane państwo przekracza próg nowoczesności dopiero wtedy, gdy osiąga zdolność do przeprowadzenia zagłady.

Zgładzenie wybranej społeczności nie jest bowiem zadaniem o charakterze doraźnym, dającym się rozwiązać za pomocą środków jednorazowego użytku. Aby dokonać eksterminacji, trzeba móc prawnie wyodrębnić określoną grupę ludzi z całego społeczeństwa, sporządzić ich listę, zgromadzić i przetransportować do jakiegoś miejsca, wreszcie uśmiercić, ciała zaś usunąć. Jeśli spojrzymy na to od strony warunków koniecznych, okaże się, że państwo, które planuje zamordowanie kilku milionów ludzi,

4 Henryk Grynberg, polemizujący z Baumanem, stwierdził: „Mówiono [...] o winie faszyzmu, totalitaryzmu, militaryzmu i rasizmu, choć wszystkie te «izmy» istniały w takiej czy innej formie od wieków, a holocaustu przedtem nie było. Mówiąc o holocauście, skupiono uwagę tylko na ostatnim ogniwie konkluzji, aby nie przyznać, że wywołał go chrześcijański antysemityzm, umożliwiła dwudziestowieczna technologia i biurokracja, a rasizm, totalitaryzm i faszyzm - po prostu wykonał"; H. Grynberg Ludzie Żydom zgotowali ten los, w: tegoż Prawda nieartystyczna, PIW, Warszawa 1994, S. 105-106. 
potrzebuje: 1) ustabilizowanego prawa (które pozbawi część obywateli ich praw, czyniąc z nich istoty gorszego gatunku); 2) rozbudowanego aparatu administracji (spisów ludności uwzględniających kategorie różnicujące); 3) sieci komunikacyjnej (potrzebnej do masowego transportu); 4) technologii masowego zabijania i utylizowania zwłok.

W ujęciu Baumana dominuje chłód: prawo, administracja, transport, technologia. Według autora Nowoczesności i Zagłady właśnie ów chłód, charakterystyczny dla nowoczesnego państwa, był warunkiem powodzenia Holokaustu. To prawda, że Niemcy na wczesnym etapie ostatecznego rozwiązania, po wkroczeniu do jakiegoś państwa, potrafili rozbudzać nastroje antysemickie, a więc odwoływać się do zbiorowych zachowań żywiołowych. Chwilę później jednak uśmierzali te samorzutne inicjatywy, by przystąpić do rozmów z Żydami i powiedzieć im, że wobec wrogości rdzennych mieszkańców danego kraju (Czech, Polski, Francji, Litwy...) konieczne jest, by Żydzi przenieśli się do getta. Odizolowanie od nacjonalistów i antysemicko nastawionej ludności - perswadowali Niemcy - uchroni Żydów przed wybuchami nienawiści i zapewni względne bezpieczeństwo. Jeśli więc w którymkolwiek momencie Zagłady Niemcy budzili zachowania spontaniczne i rozpalali nienawiść, to dążyli do tego, by je zużytkować i natychmiast potem schłodzić.

"Zimna" interpretacja Baumana, idąca za Weberowskim rozumieniem zasady działania nowoczesnego państwa, opierała się na logicznym założeniu: w afekcie można zamordować wiele tysięcy osób, ale nie kilka milionów; można mordować masowo, ale nie można utrzymać precyzji zabijania. Do takiego zadania potrzebna jest zimna perfekcja zabójców i obojętność świadków. Dlatego Bauman przytacza wycofywania "nadgorliwych" - niemieckich żołnierzy, którzy emocjonalnie angażowali się w zabijanie. Powodzenie akcji „ostateczne rozwiązanie kwestii żydowskiej”zależało od ścisłego wykonywania rozkazów, a więc od wytłumienia odruchów i działań spontanicznych.

Istotne uzupełnienie rozważań Baumana stanowią badania Raula Hilberga. W studium Sprawcy, ofiary, świadkowie. Zagłada Żydów 1933-1945 (1992; wyd. polskie: 2006) autor przełamał dominujące we wcześniejszych opracowaniach ograniczanie analiz do dychotomicznej relacji „prześladowcy - prześladowani” i opisał mechanizmy, dzięki którym Niemcy zacierali granicę między "sprawstwem” $i$ „brakiem udziału”, wciągając do współpracy świadków. Zabójcze "nowatorstwo" nazistów polegało na tym, że uczynili z ludności cywilnej konieczny warunek skuteczności Zagłady; odwoływanie się do tradycji lokalnych antagonizmów, oferowanie korzyści za donosy, wciąganie do "zwykłej" współpracy gospodarczej przy budowie obozów koncentracyjnych, nakładanie wyroków śmierci za niesienie pomocy czyniło obojętność świadków normą i zarazem uszczelniało izolację Żydów. Praktyki nazistowskie prowadziły do wyobcowania sytuującego Żydów poza obszarem tego, co ludzkie, i czyniącego z nich istoty podległe „normalnemu złu”. 
Właśnie w tym miejscu ze środka refleksji nad Zagładą wyłania się ścieżka wiodąca w stronę historii środowiskowej. Jeśli do tej pory zdążyliśmy dowiedzieć się, że Zagłada była zbrodnią masową dokonaną przez masy na oczach mas, to koncepcja środowiskowa nakazuje dodać do tego jeszcze jeden - choć nader istotny - parametr: lokalizacja. Getto, stacja kolejowa, trasa transportu, las jako scena masowej egzekucji, obóz koncentracyjny, obóz eksterminacyjny, komora gazowa zawsze znajdowały się gdzieś, zajmując określone miejsce należące do rozleglejszej przestrzeni. Badanie owych miejsc w równym stopniu korzysta z refleksji ekologicznej, co z ustaleń Hilberga5. Środowisko, czyli konkretna przestrzeń ze swoimi uwarunkowaniami, jest więc interpretowane jako "naturalny" wróg (bagienne okolice obozu) bądź „naturalny” sojusznik (zalesione okolice obozu) ${ }^{6}$, jako świadek (który do roli świadka został przymuszony, ale przechował do dziś ślady dawnej zbrodni) bądź wreszcie jako ofiara (niszczona równie systematycznie, jak ludzie).

Artykuły w niniejszym zeszycie "Tekstów Drugich" proponują panoramę ujęć związanych z badaniem środowiskowej historii Zagłady. Wspólne jest im uwzględnianie tych aspektów, które podlegały słabszej kontroli prześladowców bądź kontroli się wymykały. Niemcy w ramach przeprowadzania Zagłady dążyli do zapanowania nad życiem wybranych grup ludzkich i nad uwarunkowaniami ich śmierci; skupiali się na relacjach międzyludzkich, na regułach sprawowania władzy i gwarancjach skuteczności procedur. Patrzyli na świat z perspektywy ludzi, uznając to, co pozaludzkie, za obdarzone słabszym istnieniem bądź zgoła za nieistniejące.

Odkrycie owej ontologii jest pierwszą zdobyczą środowiskowych badań nad Zagładą. Pozwalają one retrospektywnie zobaczyć ontologię wąskiego antropocentryzmu: dla prześladowców istniało tylko to, co potrafiło walczyć, mówić i nie znikało z pola widzenia; reszta, nawet $w$ ramach troski, podlegała nacjonalistycznej instrumentalizacji. Naziści nie wymyślili jednak tej postawy: wynieśli ją z domów i szkół, z kultury

5 Jak zwykle, można przy tej okazji nadmienić, że literatura od początku "tu była" - czekając z licznymi opisami lasów, zagajników, wsi, pól, krajobrazów, pór roku, klimatu czy temperatur. Co więcej, od samego początku pisarze stosowali język łączny, zmieszany, zacierający granicę ludzkie-pozaludzkie. W Kamiennym potoku (powst. 1946; wyd. cyt.: L. Buczkowski Kamienny potok, KAW, Warszawa 1986) napotykamy dwuznaczne metafory („Na południu stała sina, tęga zapora lasu”, s. 22; "Wyleniały krajobraz jest wrogiem tropionego człowieka", s. 58) opisujące naturę jako kolaboranta Zagłady, a wojnę portretujące jako zjawisko osadzone w naturze („zamieć kul”, s. 48). Dość liczne są również teksty, w których środowisko znajduje się na pierwszym planie - zob. np. J. Hen Kłopot z psem (1958); Ch. Delbo Auschwitz et après (trylogia: 1965, 1970, 1971; zwłaszcza tom pierwszy: Żaden z nas nie powróci, przeł. K. Malczewska-Giovanetti, Państwowe Muzeum Auschwitz-Birkenau, Oświęcim 2002); S. Głąbiński Psy, ludzie, zwierzęta, Czytelnik, Warszawa 1986.

6 Zob. Natural Enemy, Natural Ally: Toward an Environmental History of Warfare, ed. by E.P. Russell, R.P. Tucker, Oregon State University Press, Corvallis 2004. 
narodowej i europejskiej’. Można powiedzieć, że podczas Zagłady przenieśli na ludzi instrumentalne okrucieństwo, którego wcześniej nauczyli się wobec natury i które po wojnie z powrotem naturze zaaplikowali. Jeśli zatem Adorno uważał, że faszyzm jest logiczną konsekwencją kapitalizmu, zaś Bauman - że Zagłada jest logicznym następstwem rozwoju nowoczesnego państwa, to historia środowiskowa pozwala dodać do owych lakonicznych stwierdzeń jeszcze jedno: zagłada jest następstwem włączenia środowiska w procesy nowoczesnej produkcji - stała się więc możliwa nie wtedy, gdy założono pierwszy obóz koncentracyjny, lecz wtedy, gdy założono pierwsze farmy przemysłowego chowu zwierząt. Wszystkie społeczeństwa nowoczesne praktykowały na zwierzętach i środowisku naturalnym ontologiczną obojętność - genocyd stał się rezultatem przesunięcia metod stosowanych wobec środowiska, a nie wynalezienia radykalnie nowej machiny eksterminacyjnej.

Z tej perspektywy hasło "Nigdy więcej Auschwitz!" - sterujące powojennymi procesami denacjonalizacji w granicach międzyludzkich - było nie tyle połową zadania, ile zadaniem źle postawionym. Aby sformułować je inaczej, badania środowiskowe wprowadzają na scenę poszerzone grono świadków, choć świadkowie ci raczej stawiają opór, niż walczą, mówią w języku innym niż ludzki i stają się widzialni dopiero po przestrojeniu widzenia. Zmieniona ontologia pociąga za sobą konieczność nauki komunikacji biosemiotycznej: ślady zbrodni skryte w ziemi komunikują coś językiem innej wegetacji, bujniejszej bądź zakłóconej płodności, językiem ran zadanych krajobrazowi i blizn, którymi środowisko pokryło dawne zranienia. Badanie tych śladów zakłada przekroczenie dualizmu kultura-natura, który stanowił w okresie Zagłady podstawę wykluczenia społeczności z obszaru kultury i który legitymizował instrumentalne traktowanie natury.

Odsłonięcie historyczności i podważenie absolutności granicy, którą niegdyś ustanowiono dla oddzielenia tego, co ludzkie, od tego, co pozaludzkie, dokonuje się również przez opisanie paralelności obu światów. W ramach działań przygotowawczych do Zagłady często poddawano wybrane miejsce przyspieszonym zmianom: niwelowano teren, dokonywano wycinki drzew bądź - dla ukrycia zbrodni - pośpiesznie jakiś teren zalesiano, zasypywano piaskiem bądź wielokrotnie przekopywano dla znalezienia i usunięcia dowodów. Z kolei po ustaniu Zagłady wydzielano obszar na prawach specjalnych (muzeum, cmentarz, miejsce pamięci) albo omijano teren jako "przeklęty" (co powodowało jego "dziczenie"). Jeśli Zagłada, zgodnie z wolą Niemców, miała być przestępstwem idealnym - bez świadków i bez śladów - to środowisko, niczym przeoczony, acz oczywisty współuczestnik, okazuje się plątaniną głosów i dowodów. Aby

7 Zob. How Green Were the Nazis? Nature, Environment and Nation in the Third Reich, ed. by F.J. Brüggemeier, M. Cioc, T. Zeller, Ohio University Press, Athens 2005. 
tych pierwszych wysłuchać, a drugie zebrać, trzeba uwzględnić aktorów pozaludzkich - złożone i posługujące się wieloma językami kolektywy ontologiczne. Co więcej, praktyk nowej komunikacji należy szukać najpierw "na miejscu” - tam, gdzie zbrodnia się dokonała. Społeczności lokalne, nawet reagujące lękiem czy wstrętem na „nie-miejsce $^{\prime \prime}$, stopniowo wypracowywały szczątkowy język komunikacji poskładany z gestów i połowicznych rytuałów, quasi-system odczytywania śladów po Zagładzie jako znaków środowiskowego tekstu, przekształcający miejsca śmierci w „zielone macewy” .

Paralelność losów środowiska względem świata ludzkiego polega więc na tym, że obie strony przechodziły podobne procesy degradacji i regeneracji: jednostkowe i zbiorowe ciało ludzkie, jednostkowa i zbiorowa pamięć społeczna podlegały tym samym, co środowisko zranieniom, potem zaś, po ustaniu Zagłady, pojawiały się symetryczne zbliznowacenia i protezy, zrosty i jałowienie, martwota bądź zmiana rytmów płodności. Wszystkie te znaki są śladami i etapami biosemiotycznego procesu, który rozgrywał się po obu stronach. Środowiskowa historia Zagłady najpierw prowadzi obserwację paralelizmów, by w ostateczności zapytać o możliwość zamazania granicy oddzielającej oikos od człowieka. Spełnienie owej możliwości wymaga eksperymentalnego odnoszenia pojęć - takich np. jak postpamięć czy cierpienie ${ }^{10}$ - do całego środowiska, bez oddzielania podmiotów ludzkich od pozaludzkich.

Czytanie ekologiczne jest zasadniczo odwracaniem proporcji i perspektyw: aktorów z drugiego i trzeciego planu (zwierzęta, rośliny, krajobraz) rozpatruje się w powiązaniu z planem pierwszym, a historia opowiedziana z perspektywy ludzkiej zostaje ujęta z perspektywy rośliny, zwierzęcia, rzeki czy ekosystemu. Nie jest rzeczą prostą zastosowanie owej strategii do Zagłady - wydarzenia wystarczająco potwornego w granicach tego, co "ludzie ludziom" - dlatego środowiskowa historia Holokaustu to nie tyle spójna metoda badawcza, ile szkoła poskładana z wielu różnych, nie zawsze komunikujących się ze sobą klas. Kilka pytań zadają w tej szkole wszyscy: gdzie? kiedy? w jakich okolicznościach? dzięki jakim zastanym właściwościom środowiska i dzięki jakim właściwościom wytworzonym? według jakich metod i na podstawie jakich tradycji? Ale poszczególne "klasy” w poszukiwania odpowiedzi badają: ziemię, roślinność, zwłoki, pozostałości materialne, odpady, poholokaustowe losy środowiska, systemy komunikacji. Każda z submetod jest w znacznej mierze niedomknięta i eksperymentalna: służy nie tylko konkretnym dociekaniom, lecz także testowaniu, czego jeszcze możemy dowiedzieć się z analizy pozaludzkich aktorów środowiska Zagłady. Eksperymentalnie zadaje

8 Zob. w niniejszym zeszycie - Roma Sendyka, Nie-miejsca pamięci i ich nie-ludzkie pomniki.

Zob. w niniejszym zeszycie - Agnieszka Kłos, Zielona macewa. 
się tutaj nowe pytania - o ekologiczne aspekty Zagłady (pisze o tym w niniejszym zeszycie Mikołaj Smykowski), o śmieci w getcie (Jacek Leociak), o ekofakty (Aleksandra Ubertowska), o klimat (rozważania Marty Tomczok) czy o pogranicze obejmujące ekoi nekrologię (Ewa Domańska); stawiając nowe pytania, badacze wchodzą na obszar koniecznej współpracy z geografią, geologią, biologią czy badaniami sądowymi w zakresie nekrosemiotyki. Następuje więc swoiste wyrównanie: środowiskowa historia Zagłady, odwołując się do ontologii relacyjnej, sama staje się dziedziną relacyjną. Nie da się uprawiać wiedzy o Zagładzie bez nowej ontologii i nie da się pomyśleć nowej ontologii bez wyjścia poza bezpieczną przystań antropocentrycznie zorientowanego analizowania tekstów.

Skoro jednak aplikacja metody opiera się na ustawicznym podważaniu wystarczalności języka ludzkiego i ludzkiego systemu percepcji, na kwestionowaniu antropocentryzmu i fingowaniu postawy nieantropocentrycznej, na poszerzaniu pola widzenia i redefiniowaniu sprawczości, nie od rzeczy będzie postawić jeszcze jedno pytanie: czy skierowana w przeszłość nauka nowego rozumienia środowiska może posłużyć innemu patrzeniu na dzisiejsze otoczenie?"1 Czy kategorie wypracowane przez środowiskową historię Zagłady mogą okazać się pomocne w interpretacji innych - współczesnych i przyszłych - problemów ekologicznych? Podstawą pytania jest wspólne podłoże rozwoju technologii genocydu i ekocydu: od narodzin epoki przemysłowej droga wiodła do pierwszych przemysłowych farm hodowlanych (początek XIX wieku) i obozów koncentracyjnych (schyłek XIX wieku) ${ }^{12}$.Z doświadczeń gromadzonych na farmach korzystali konstruktorzy obozów, zaś po II wojnie, odwrotnie, architekci ubojni i farm hodowlanych studiowali projekty obozów ${ }^{13}$. Rozległa infrastruktura służąca hodowli zwierząt,

11 A także, czy możliwe są porównawcze studia środowiskowe nad masowymi zabójstwami - ujmujące, umownie, Hiroszimę, Kołymę, Auschwitz i Drezno (czyli miejsca eksterminacji atomowej, lodowej, gazowej i bombowej). Zob. Images of Rupture Between East and West: The Perception of Auschwitz and Hiroshima in Eastern European Arts and Media, ed. by U. Heftrich, R. Jacobs, B. Kaibach, K. Thaidigsmann. Universitatsverlag Winter, Heidelberg 2016.

Zob. A.J. Kamiński Koszmar niewolnictwa. Obozy koncentracyjne od 1896 do dziś. Analiza, Przedświt, Warszawa 1990.

13 Pisze o tym Charles Patterson - zob. tegoż Wieczna Treblinka, przeł. R. Rupowski, Vega!POL, Opole 2003. Wśród prekursorów ekologicznego myślenia przekraczającego granicę ludzkie-pozaludzkie szczególne miejsce należy się, wspomnianemu przez Pattersona, niemieckiemu więźniowi Dachau Edgarowi Kupfer-Koberwitzowi, który w trakcie czteroletniego pobytu w KL stworzył manifest braterstwa ze zwierzętami. W tekście (pisanym z narażeniem życia, schowanym po ukończeniu, wydobytym ze schowka już po wyzwoleniu obozu) stwierdzał: „[...] dopóki zabija się i dręczy zwierzęta, dopóty będzie się zabijać i dręczyć ludzi, dopóty też będą trwały wojny bowiem zabijanie ćwiczy się i doskonali na małą skalę, tak w myślach, jak i w czynach. [...] Dopóki istnieją zwierzęta-niewolnicy, dopóty wciąż będą istnieć ludzie-niewolnicy - bowiem zniewala- 
lasów i zbóż, bezprecedensowa pod względem skali w dziejach ludzkości, tworzy naturę drugiego stopnia. Funkcjonowanie tej infrastruktury jest nastawione nie tyle na maksymalizację ludzkiej sprawności w zabijaniu, ile - przeciwnie - na maksymalizację efektywności w przymuszaniu do życia. Wydaje się, że rozgałęziona, poszerzająca pole współpracy środowiskowa historia Zagłady zmierza na spotkanie z teraźniejszością. Tu, dziś, wokół, na granicy pola widzenia, środowiskowa historia eksterminacji przybiera postać eksterminacyjnej historii środowiska ${ }^{14}$. Pytania, kryteria wyboru badanych obiektów i systemy sprawdzeń powinny objąć poszerzone pole Zagłady.

nie ćwiczy się i doskonali na małą skalę, tak w myślach, jak w czynach" (E. Kupfer-Koberwitz Die Tierbrüder. Betrachtung zum ethischen Leben, Liland-Verlag, Hamburg 2010, s. 76); za zwrócenie mi uwagi na książkę Kupfer-Koberwitza, a także za użyczenie tłumaczonego fragmentu dziękuję Katarzynie Kończal, która poświęciła postaci niemieckiego jeńca partię swojego doktoratu - zob. K. Kończal Sygnatury Sebalda: zwierzęta - widma - ruiny (2017; praca niepublikowana).

14 Określenia "eksterminacja krajobrazu” (nie w odniesieniu do Holokaustu, lecz dla nazwania współczesnych procesów przemysłowych) użył Mariusz Kistowski - zob. tegoż Eksterminacja krajobrazu Polski jako skutek wadliwej transformacji społeczno-gospodarczej państwa, w: Studia krajobrazowe a ginqce krajobrazy, red. D. Chylińska, J. Lach, Uniwersytet Wrocławski, Wrocław 2010. 


\section{Abstract}

\section{Przemysław Czapliński}

ADAM MICKIEWICZ UNIVERSITY IN POZNAŃ

Broadening the Field of the Holocaust

Czapliński reads the environmental history of the Holocaust as a reflection on the relationship between mass death and its localization. This concept - which brings together looselyrelated or even unrelated practices - has emerged on the intersection of Holocaust studies, ecology and posthumanism. Its retrospective effect is an ontological shift in Holocaust research: the environment comes to be perceived as a place, as a witness, an ally or even accomplices of the genocide. A further consequence, it seems, is the necessity to broaden the field of research, facilitating the transition from an environmental history of the extermination to an exterminatory history of the environment.

\section{Keywords}

Holocaust, ecology, posthumanism, environmental history of the Holocaust, exterminatory history of the environment 